www.jmscr.igmpublication.org

Impact Factor 5.244

Index Copernicus Value: 5.88

ISSN (e)-2347-176x ISSN (p) 2455-0450

crossref DOI: http://dx.doi.org/10.18535/jmscr/v4i6.75

Journal Of Medical Science And Clinical Research

IGM Publication

An Official Publication of IGM Publication

\title{
An Evaluation of the Needs among Differently Abled Population
}

\author{
Authors \\ Dr S.S. Subramanian ${ }^{1}$, Dr A. Siva Subramanian ${ }^{2}$ J Jayaraj $^{3}$ \\ ${ }^{1}$ BPT, MPT, MS, M.Phil, PhD, Sree Balaji College of Physiotherapy, Chennai, Tamilnadu, India, \\ ${ }^{2}$ MBBS, MD, Chief Medical Officer, S.G.S Trust. \\ ${ }^{3}$ BPT, MPH, MD candidate School of Public Health, American University of Armenia, Yerevan, Armenia, \\ Corresponding Author \\ S.S. Subramanian \\ Add: Sree Balaji College of Physiotherapy, Velachery main road, Narayanapuram, \\ Pallikaranai, Chennai 600 100, Tamilnadu, India \\ Phone: (91) 044-22461883, Email: s.s.subramanian@hotmail.com
}

\begin{abstract}
Objectives: The study evaluated the needs of the differently-abled population from the society, the government on their problems on jobs placement and the perception of their physical challenges, Kanchipuram District, South India.

Background: Reasons for problems on jobs placement are multifactorial - often related to society, government, individual and socioeconomic factors.

Methods: The analytical cross-sectional survey used a convenient sample of patients aged 18 and over who were differently abled identified during the rural monthly camp from January to December, $2014(n=300)$ at Kanchipuram, Tamilnadu, India.

Results: Most of the respondents were male and about $45 \%$ of respondents were above 50 years. About $73 \%$ reported below the poverty line, and $66 \%$ have more expectation from the government. Respondents were most often cited out- of - pocket costs as a reason for noncompliance (19\%). Age, gender, visual disability, the dependency for selfcare and stressful relation associated with problems in findings a job $(p<0.05)$.

Conclusion: This study demonstrated that there is a relationship such as between and literacy with poverty as well and utilising rehab services between Nature of Disability and Employment. Strategies to provide jobs for differently abled persons should improve their quality of life and, thus, economy outcomes. These findings further efforts to benchmark performance in India against Western standards and experiences.

Keywords: differently abled needs; rural areas of India; needs-based assessment; survey; India
\end{abstract}

\section{Introduction}

$15 \%$ of world population suffers from some kind of disability, (WHO 2011) with $2.21 \%$ of Indians as disabled among which rural disabled at $2.43 \%$ Tamilnadu, the only state having higher number of disabled female than male (Census 2011).
Disability is an important public health problem especially in developing countries because of increase in trend of non communicable diseases and change in age structure with an increase in life expectancy (Ganesh Kumar etal 2012). The Paradigm shift from the welfare and charity 
approach to rights based one towards the issues concerning persons with differently abled (1995 Act). Increase in life expectancy means by the year2020, 60\% of the population will be more than 60 years (WHO 2013)and so old age related issues leading to physical challenges requires an insight into planning and prevention changes in lifestyle, lack of physical activities, obesity, stress factors, increasing state of diabetes mellitus as all these show direction towards the risk of community which may lead to disability. chronic condition including injuries, mental disorders will be responsible for $78 \%$ of the global disease burden in developing countries (WHO 2013) India cannot dream of becoming developed nation as envisioned by Dr.APJ .Abdul Kalam if only various needs of people who are otherwise abled are addressed with, this original study aims at assessing and analyzing needs of the differentlyabled population of Kanchipuram district.

\section{Methods}

300 differently-abled population who have attended special rural camps conducted in
Kanchipuram district included in this study during the period from January 2014 to December 2014.

Oral informed consent was obtained from each patient before asking questions to assess medication compliance and satisfaction with treatment. The study protocol complies with the Declaration of Helsinki as reflected in a priori approval by the Institutional Review Board (IRB) of the Sree Balaji College of Physiotherapy.

\section{Study instrument and outcomes}

Observational, questionnaire of all the subjects were given a 10 point closed-ended questionnaire, and data are processed, those who are illiterate, information related to the questionnaire were filled up by the investigator.

\section{Data Analysis}

Data were entered into an SPSS dataset, cleaned and recoded for further analysis. Differences in characteristics of differently abled persons were compared using either a standard 2-tailed t-test (for continuous variables) or a $\chi^{2}$ test (for dichotomous variables).

\section{Results}

Table 1: Displaying a Gender, Age, Nature of Disability.

\begin{tabular}{|c|c|c|c|}
\hline 1 & 2 & & 3 \\
\hline Table & Age & Years & Nature of Disability \% \\
\hline Gender & $<10$ & $25 \%$ & Locomotor 26 \\
\hline Male $57 \%$ & $11-50$ & $30 \%$ & Visual \\
\hline Female $43 \%$ & $>50$ & $45 \%$ & Mental Retardation 14 \\
\hline
\end{tabular}

Table 2: On Literacy, Poverty.

\begin{tabular}{|c|c|}
\hline 4 & 5 \\
\hline Literacy $\%$ & Poverty $\%$ \\
\hline Illiterate 67 & Poor 73 \\
\hline Primary 30 & Non Poor27 \\
\hline Elementary 8 & \\
\hline NSC 2 & \\
\hline
\end{tabular}


Table 3: On Expectations, Rehab Services and Employment of all participants.

\begin{tabular}{|l|l|l|}
\hline 6 & 7 & 8 \\
\hline Expectations \% & Rehab Services \% & Employment \% \\
\hline Govt 66 & Aware 22 & Self \\
\hline Family 10 & Unaware 78 & Salary \\
\hline Both 24 & & Casual Lbourers30 \\
\hline & & Not Applicable 41 \\
\hline
\end{tabular}

Table 4: Results of $x^{2}$ test literacy and poverty, nature of disability and employment and literacy and rehab services:

\begin{tabular}{|l|c|c|c|c|c|}
\hline S.No & & $\mathrm{X}^{2}$ & $\mathrm{Df}$ & Table value & Level of Significance \\
\hline 1 & $\begin{array}{c}\text { Relationship between } \\
\text { literacy and poverty }\end{array}$ & 42.50 & 4 & 9.49 & $\mathrm{X} \mathrm{P}<.05$ \\
\hline 3 & $\begin{array}{c}\text { Nature of disability and } \\
\text { employment }\end{array}$ & 53 & 12 & 9 & $\mathrm{XP}<.05$ \\
\hline Literacy and rehab services & 98.41 & 8 & 15.51 & $\mathrm{X} \mathrm{P}<.05$ \\
\hline
\end{tabular}

$\mathrm{X}$ significant

\section{Discussion}

1. In India, Majority of the disabled resides in rural areas, where accessibility, availability, utilization of rehabilitation services, its cost effectives, appropriate intervention strategies and implementation on disability are big challenge in the present context. The burden of disability is more among the geriatric population (NSSO 2002).More disability among male (NSSO 2002). Similar to this, $57 \%$ of this study subjects are male. The lancet 2010 have reported with a rise in life expectancy, for men (64 years) and women (68 years) in India at an average of 8.6 years gained since 1990, While the fact is people spend on average 8 years or $11.5 \%$ of their life span, living with disabilities, in countries with life expectancies over 70 years of age (WHO) Owing to the combination of population size and high disease and injury rates, India and china accounts for nearly $40 \%$ of the total years lived with disability (Murray etal 1998). with $45 \%$ of this study Subjects are above 50 years being disabled and added disability with ageing requires further care and attention.

2. $73 \%$ of this study subjects are below poverty line, even in developed countries as in U.S $50 \%$ of the children live in poverty as reported in 2016 by national center for children, Columbia University. Also recent publications in 2016 from Duke University molecular psychiatrist that living in poverty can cause changes to peoples DNA that makes them more likely to be depressed, anxious and possibly take drugs.

3. Lack of education among disabled is an important barrier for effective delivery of services and $54.7 \%$ of disabled are 
illiterate (NSSO 2002). 51\% of PWD are illiterate, $26 \%$ reach upto primary, $6 \%$ middle and only $13 \%$ secondary above (Census 2011) 67\% of this study locomotion which is a rural area, subjects are illiterate. Very few disabled people gets benefit from rehab services in India (Kumar etal 2008).

4. $68 \%$ of disabled Indian lives in rural areas Census 2011. With 78\% of this study subjects are unaware of various rehabilitation services which is supported by following reports: An estimated 2\% of people with disabilities in developing countries have access to rehabilitation and appropriate basic services (International Development Report 2000). A rural study conducted in Maharashtra state of India with $6 \%$ of the people with disability, continued to avail any medical rehabilitation services (Vaid Rajeev and Telang 1997). It was pointed out by Patel and Ladu sing 2009, that treatment seeking behavior of disabled persons depends not only on socio economic factors but also on cultural factors, area of residence, literacy status, sex etc.

5. $30 \%$ of this study subjects are casual labourers, when compared to Americans with disability, where $35 \%$ are employed on full time (Harris Survey 2004). With only $7 \%$ of persons with disability in India have succeeded in obtaining employment in industry and unemployment among persons with disabilities is as high as $80 \%$ in many countries (ILO) and there is considerable need for the improvement of facilities, services and opportunities for the disabled (Pal etal 2000).

6. The inability to perform some key activities such as mobility, feeding personal hygiene due to disability leads to dependency, such help is given by care givers or family members (MRC 1999) with dependency ratio of India at $12 \%$ and china at $14 \%$ an identification of human and financial resources to support them is required (Har Wood 2004) while 13\% of this case study subjects are totally dependant for self care.

\section{Efforts Taken By Govt of India for PWD}

7. $3 \%$ reservation for PWD as enacted by govt of India in 1997. Public sector out of $4.46 \%$ identified post only $44 \%$ filled up in India. Few measures worthy mentioning with steps taken by govt of India includes 100 new DDRC sanctioned in $11^{\text {th }}$ plan with an objective of providing comprehensive services to the persons with disabilities services to the persons with disabilities at the grass root level. National policy for persons with disability 2005 with service delivery system for CBR.

\section{Limitations}

The study was questionnaire based, with no medical examination record analysis, measurement of disability were not done. Further study with more disabled subjects and percentage of disability evaluation are recommended.

\section{Conclusion}

With more awareness to be generated among and disabled community based rehabilitation at rural areas about their rights, services available to be brought to their living locality conducting disability based medical camps, issuing of due certificates on the percentage of disability, helping for further medical, referral services, creating job opportunities to suit their physical potential, improving socio economic status of are need of the hour policy makers, Govt, NGOS, Medical Professionals, Family members of the affected victim together can improve the livelihood and dignity of the disabled. 


\section{Acknowledgments}

- Sree Balaji College of Physiotherapy, Chennai - 100 .

- $\quad$ S.G.S trust, Chennai - 42 .

- All The Subjects, Volunteers who Participated and Coordinated in the Camps.

\section{References}

1. World report on disability Geneva: who, 2011 WHO

2. Census of India 2011, data on disability, office of the registrar general and census commissioner, India New Delhi.

3. S Ganesh Kumar, Gautam Roy and sitanshu sekrar kar. Disability and rehabilitation services in India: issues and challenges. J Family Med Prim Care. 2012 Jan-Jun; 1(1): 69-73.

4. Equal opportunities, protection of rights and full participation Act 1995. Interpretation of Persons with Disability (Equal Opportunities, Protection of Rights and Full Participation) Act 1995, Mansi Trivedi, Nirma University, Ahmedabad, January 11, 2011.

5. WHO Global Health Observatory data (GHO) on Life expectancy 2013.

6. WHO report on Life Expectancy 2013.

7. Survey of Disabled Persons, NSSO 2002 $58^{\text {th }}$ Round on Disabled persons.

8. Lancet 2010 on life expectancy.

9. Murray CJ, Lopez A.D. Quantifying disability: Data methods and results bull world health organ 1994: 4 81-94.

10. Yang Jiang, Mercedes Ekono, Curtis Skinner. Basic Facts about Low-Income Children under 3 Years, 2014. National center for children, Columbia University 2016.

11. Courtesy of Ahmad Hariri lab, Duke University. Poverty marks a gene, predicting depression. May 24, 2016.
12. Disability poverty and development. Department for international development report INF official journal 2000; 38:1.

13. Vaid Rajeev, Telang Assessment of persons with disability in the rural community of Maharashtra. IAP 2007.

14. Patel S k, Ladu Sing L. Age pattern of onset of disability and treatment seeking behaviour of disabled persons in India, XXVIIUSSP international population conference: url:http://iussp2009. Princeton edu/ abstracts/91173.

15. Kumar SG, Das A, Soans SJ. Quality of rehab services to disabled in a rural community of Karnataka Indian J comm. Med. 2008, 33:198-200.

16. www.ilo.org/ publns 2011. Persons with disability and the Indian labour market challenges and opportunities.

17. http://www.nod.org National Organization on Disability. N.O.D./ Harris Survey of Americans with Disabilities2004.

18. Pal HR, Saxena S, Chandrasekhar K, Sudha SJ, Murthy RS, Thara R etal. Issues related to disability in India: A focus group study Nat Med J India 2000; 13:237-41.

19. Medical research council: cognitive function and ageing study: profile of disability in elderly people estimates from a longitudinal population study. BMJ 1999; 318; 1108

20. Harwood RH, Sayer A.A, Hirschfield M. current and future worldwide prevalence of dependency, its relationship to total population and dependency ratios. Bull world health organ 2004; 82:251-8.

21 . District disability rehabilitation centers sanctioned 2010. http://pib.nic.in/ release 